husbands, and the prevalence of $M$. hominis in the genital tract is probably associated with sexual promiscuity.

Though mycoplasmas may cause conjunctivitis in animals (Cole et al., 1967) reports that they may do so in man are scanty. Arm et al. (1966) isolated an unidentified mycoplasma from the conjunctiva of a 5-year-old boy with conjunctivitis. Our findings indicate that mycoplasma infections of the eye in humans do occur, at least among neonates, and may be commoner than is realized.

This investigation was supported by a grant from the Manchester Regional Hospital Board.
REFERENCES

Arm, H. G., Woolridge, R. L., Cheng, K-H., and Chang, I-H. (1966). Amer. F. Ophthal., 62, 1125 .

Clyde, W. A. (1964). F. Immunol., 92, 958.

Cole B. C. Golighty, I and Ward, J. R. (1967). F. Bact., 94, 1451. Hayflick, L., and Standbridge, E. (1967). Ann. N.Y. Acad. Sci., 143, 608.

Hoogendijk, J. L., De Bruijne, J. I., and Herderscheĉ, D. (1965). Ned. T. Geneesk. 109, 1433

Jones, D. M. (1967a). Brit. med. F., 1, 338.

Jones, D. M. (1967b). F. clin. Path., 20, 633

Pease, P., Rogers, K. B., and Cole, B. C.' (1967). F. Path. Bact., 94, 460. Slingerland, D. W., and Morgan, H. R. (1952). F. Amer. med. Ass., 150, 1309.

Stokes, E. J. (1955). Lancet, 1, 276.

Tully, J. G., Brown, M. S., Sheagren, J. N., Young, V. M., and Wolff, S. M. (1965). New Engl. F. Med., 273, 648.

\title{
Carcinoma of Bronchus and the Smoking Habit in Rhodesian Africans
}

\author{
MICHAEL GELFAND,* C.B.E., M.D., F.R.C.P. ; A. J. P. GRAHAM, $†$ M.B., F.R.C.s. \\ ELAINE LIGHTMAN, B.A., CERT.STATS.
}

Brit. med. F., 1968, 3, 468-469

\begin{abstract}
Cummary : Comparison of the smoking habits of 32 adult male Africans with carcinoma of the bronchus and 32 controls showed that $87.5 \%$ of the patients with lung cancer were cigarette smokers compared with only $22 \%$ of the controls. The distribution of histological types of growth confirmed findings by other workers.

The absence of atmospheric pollution in Rhodesia makes it likely that cigarette-smoking is the most important causative factor in the aetiology of lung cancer among Rhodesian Africans. Further work is needed to determine the level of consumption of cigarettes and type of smoking habits which lead to a serious risk of cancer.
\end{abstract}

\section{Introduction}

No serious argument can be levelled against the association of carcinoma of the bronchus with smoking, more particularly that of the cigarette (Doll and Hill, 1950). It is true that there are many who consider as more responsible the carcinogens in smoke which has polluted the atmosphere in city or urban areas. But the presence of a carcinogenic hydrocarbon in cigarette cmoke is probably a far more potent factor. The contents of the atmosphere were compared by Stocks and Campbell (1955) in two areas in England-one an almost permanently smoke-bound city, the other a semi-urban community in a wholly rural part of north Wales. In a rural community, where the atmospheric pollution is minimal, the incidence of lung cancer increases progressively with the number of cigarettes smoked. The death rate from lung cancer of heavy cigarette smokers (over 35 a day) was 20 times greater than that of non-smokers and eight times greater than that of pipe smokers. Among non-smokers the lung cancer rate was much higher in the urban than in the rural areas, the urban lung cancer rate being eight times higher than the rural rate. However, as cigarette-smoking became heavier the differences tended to disappear.

Stocks and Campbell (1955) drew attention to the close correlation between the concentrations of 3:4-benzpyrene in

* Department of Medicine, University College of Rhodesia. t Cardiothoracic Surgeon, Harare Hospital, Salisbury, Rhodesia. the air (about 10 times higher in Liverpool than in Wales) and to the relative incidence of lung cancer in non-smokers (about seven times as high in Liverpool as in Wales). As one would expect, the concentration appears to increase with urbanization, depending on the proximity of industry, houses, and motor vehicles. Although they are hesitant to incriminate 3:4-benzpyrene as the villain of the piece, it is clear that Stocks and Campbell would evince little surprise if a close correlation were found between this carcinogen and lung cancer.

The African in Rhodesia smoked tobacco before Europeans entered the country in 1890. They grew their own leaf and had elaborate methods of preparing the tobacco as a "cigar," for the pipe, or for snuff. However, with the introduction of factory-made cigarettes, the African began to buy his cigarettes, but sometimes, especially when he lived in the rural villages, he continued to grow his own tobacco and rolled it into a cigarette with any paper he could find. This is still quite commonly done, much depending on his own finances. Few Rhodesian Africans have taken to the pipe. Typically, too, the cigarette is smoked to its very end.

The atmosphere in the towns of Rhodesia is, for practical purposes, purer than in the industrial towns of Europe, since pollution from industrial smoke in Rhodesia is very slight. Nor do we believe that the pollution from motor vehicles is so heavy in Rhodesia as to be a factor in the causation of lung disease. Indeed, the atmosphere in Central Africa would seem to be remarkably healthy. Veld fires are frequent and extensive, but it is very doubtful whether the atmosphere is ever polluted long enough for this to be of any direct consequence. In any case the fires are very seasonal and focal.

Africans living in tribal areas are in the habit of sitting close to the fires in their huts, and it is possible that they often sleep in a smoky atmosphere. However, sitting by smoking fires is common in countries such as the Congo, where lung cancer is said to be very rare.

One of us (M.G.) visited the Congo (Leopoldville) and Nigeria (Ibadan), where very few cigarettes are smoked by the African population because tobacco is grown only with the greatest difficulty, and found that bronchogenic carcinoma was rarely encountered. However, this is not the case in Rhodesia, where cigarette-smoking is common among the Africans. We 
began to consider whether the incidence of the disease among Africans was in any way related to their smoking habits.

\section{Present Investigation}

The object of this communication is to report findings of the study of 32 unselected African patients admitted to Harare Hospital, Salisbury, during 1959 to 1967 with proved bronchogenic carcinoma. As soon as the histological report of the biopsy material was obtained, and therefore the diagnosis of bronchogenic carcinoma established, each such patient was asked whether he smoked and if so to what extent and for how long. After this information was obtained another African of approximately the same age, sex, and background was selected at random and asked the same questions. Thus each patient was matched as closely as possible with another person of the same age and race, the intention being to reduce, so far as was possible, the influence of any environmental or other extraneous factor.

For the purpose of analysis and comment the following definitions for the smoking habits of the general population were adopted (Doll and Hill, 1956): (1) a regular smoker was one who at the time of the inquiry had been smoking as much as one cigarette a day or a quarter of an ounce $(8 \mathrm{~g}$.) of tobacco a week (in home-made cigarettes or a pipe) for at least a year ; (2) an ex-smoker was one who had been a regular smoker according to the above definition but was not at the time of the inquiry smoking as much or at all; and (3) a non-smoker was one who had never smoked as much as one cigarette a day (or a quarter of an ounce of tobacco a week or two cigars a week) for as long as a year.

\section{Results}

Thirty-two men with bronchial carcinoma were studied. The probable explanation for the lack of females is that the patients referred to Harare Hospital come from the surrounding African adult population which in this urban area is composed mostly of male labourers. Thus we have no results with which to compare the effect of smoking on each sex. In any case this would probably prove a very difficult task, since very few African women smoke.

When classifying the 32 patients with bronchial carcinoma according to certain age groups it was found that two were between 31 and 40, 17 between 41 and 50, 9 between 51 and 60, and four over 60 . Most of the patients were therefore 41 to 50 years old.

From the pathological results we found that the growth was squamous (epidermoid) in $20(62.5 \%)$ cases, oat-cell and undifferentiated in $11(34.4 \%)$ cases (two oat-cell and nine undifferentiated), and malignant in a bronchial adenoma in only one case $(3.1 \%)$.

According to the definitions of smoking habits mentioned earlier we found that $28(87.5 \%)$ of the patients were regular smokers, one was a pipe smoker, one an ex-smoker, and two were non-smokers. In the control series there were seven $(21.9 \%)$ regular smokers, 5 ex-smokers, and 20 non-smokers.

As mentioned above, 28 of the 32 patients with carcinoma were regular smokers. When grouping these 28 according to the number of cigarettes they smoked we found that $19(67.8 \%)$ smoked between 1 and 10 cigarettes a day, 5 (17.8\%) smoked between 11 and 20 per day, and only $4(14.3 \%)$ smoked over 20 cigarettes a day.

\section{Conclusions and Suggestions for Further Study}

The above results are of interest for the following reasons:

(1) The Table tests whether there is an association between bronchogenic carcinoma and smoking. ${ }^{1}$ The probability of obtaining these results, on the assumption that bronchogenic carcinoma and smoking are independent, is $<0.001$. This is a highly significant result, and we can therefore conclude that the results obtained in this study provide strong evidence in favour of some kind of association between bronchogenic carcinoma and smoking among the Rhodesian Africans.

\begin{tabular}{|c|c|c|c|c|}
\hline \multicolumn{5}{|c|}{ Bronchogenic } \\
\hline \multirow{2}{*}{\multicolumn{2}{|c|}{ Smoking }} & \multicolumn{2}{|c|}{ Bronchogenic Carcinoma } & \multirow{2}{*}{ Total } \\
\hline & & Yes & No & \\
\hline $\begin{array}{l}\text { Regular smoker } \\
\text { Non-smoker }\end{array}$ & 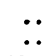 & $\begin{array}{r}24 \\
2\end{array}$ & $\begin{array}{r}7 \\
19\end{array}$ & $\begin{array}{l}31 \\
21\end{array}$ \\
\hline Total .. & . & 26 & 26 & 52 \\
\hline
\end{tabular}

1 This table includes only those participants who fall within one of the two categories-regular smoker or non-smoker. Pipe-smokers and ex-smokers are therefore excluded. Also excluded is the respective matched pair (whether patient or control) of each such pipe smoker or ex-smoker, since the pairs were mathed so such variables as age, race, etc., and therefore to include only one of a pair would invalidate the results.

(2) The results seem to confirm the findings of Winston Evans (1966) with regard to the incidence of the different cell types of bronchogenic carcinoma. He shows a fairly well marked variation between the incidence of the different cell types. For instance, he quotes one large series of 1,329 lung cancer cases in Liverpool-that of Whitwell: $42 \%$ were squamous carcinoma, $33.5 \%$ oat-cell carcinoma, $16.8 \%$ undifferentiated carcinoma, and $2 \%$ adenocarcinoma. In another series of 907 cases from the same region, by the same author, $54 \%$ were squamous cell carcinoma, $15.2 \%$ oat-cell carcinoma, $16.9 \%$ undifferentiated carcinoma, and $10 \%$ adenocarcinoma. In our much smaller series the trend was similar: $62.5 \%$ were squamous carcinoma, $6.2 \%$ oat-cell carcinoma, $28.2 \%$ undifferentiated, and $3.1 \%$ adenocarcinoma. The general tendency therefore appears to be that squamous carcinoma is the most common and adenocarcinoma the least common type of growth, with oat-cell and undifferentiated carcinoma somewhere in between.

We consider that our findings justify further studies into carcinoma of the bronchus in the African with regard to his smoking habits. In particular, we should like to know how often Africans who smoke only their own-made cigarettes develop carcinoma. This is not likely to be easy, as many of the cases in the present series smoked factory-made cigarettes when in town, but when they returned to the villages they smoked cigarettes made by themselves. We would also want to know more about the inhalation of cigarette smoke. Our opinion so far is that the great majority of Africans inhale, and, further, almost all smoke their cigarettes to the very end. Lastly, we feel that these results may point to lung cancer developing in the African when only a comparatively small number of cigarettes are smoked.

\section{REFERENCES}

Doll, R., and Hill, A. B. (1950). Brit. med. F., 2, 739.

Doll, R., and Hill, A. B. (1956). Brit. med. f., 2, 1071.

Evans, R. W. (1966). Histological Appearances of Tumours, 2nd ed., p. 1106. Edinburgh and London.

Stocks, P., and Campbell, J. M. (1955). Brit. med. F., 2, 923. 